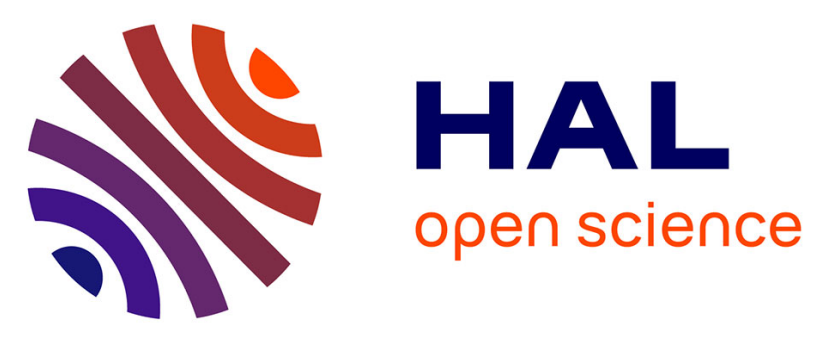

\title{
Anthropogenic charcoal-rich soils of the XIX century reveal that biochar leads to enhanced fertility and fodder quality of alpine grasslands
}

I. Criscuoli, S. Baronti, G. Alberti, C. Rumpel, M. Giordan, F. Camin, L. Ziller, C. Martinez, E. Pusceddu, F. Miglietta

\section{To cite this version:}

I. Criscuoli, S. Baronti, G. Alberti, C. Rumpel, M. Giordan, et al.. Anthropogenic charcoal-rich soils of the XIX century reveal that biochar leads to enhanced fertility and fodder quality of alpine grasslands. Plant and Soil, 2017, 411 (1), pp.499-516. 10.1007/s11104-016-3046-3 . hal-01469413

\section{HAL Id: hal-01469413 \\ https://hal.sorbonne-universite.fr/hal-01469413}

Submitted on 16 Feb 2017

HAL is a multi-disciplinary open access archive for the deposit and dissemination of scientific research documents, whether they are published or not. The documents may come from teaching and research institutions in France or abroad, or from public or private research centers.
L'archive ouverte pluridisciplinaire HAL, est destinée au dépôt et à la diffusion de documents scientifiques de niveau recherche, publiés ou non, émanant des établissements d'enseignement et de recherche français ou étrangers, des laboratoires publics ou privés. 
Anthropogenic charcoal-rich soils of the XIX century reveal that biochar leads to enhanced fertility and fodder quality of alpine grasslands

I. Criscuoli. ${ }^{1,6 *}$, S. Baronti ${ }^{2}$, G. Alberti ${ }^{3,4}$, C. Rumpel ${ }^{5}$, M. Giordan 7 , F. Camin ${ }^{7}$, L. Ziller ${ }^{7}$, C. Martinez ${ }^{1}$, E.Pusceddu ${ }^{2}$, F.

${ }^{1}$ Foxlab Joint CNR-FEM Initiative, Via E. Mach 1, 38010 San Michele all'Adige, Trento, Italy

$8{ }^{2}$ Institute of Biometeorology, National Research Council (IBIMET-CNR), Via Caproni 8, 50145 Firenze, Italy

$9{ }^{3}$ University of Udine, Dipartimento di Scienze Agro-Alimentari, Animali ed Ambientali, via delle Scienze, 206, 33100, 10 Udine, Italy, Currently at Chair of Silviculture, Faculty of Environment and Natural Resources, University of Freiburg, 11 Tennenbacher str. 4, 79085 Freiburg, Germany

${ }^{4}$ The EFI Project Centre on Mountain Forests (MOUNTFOR), Edmund Mach Foundation, via Edmund Mach 1, 38010 San Michele all'Adige, Trento, Italy ${ }^{5}$ CNRS, IEES, Campus AgroParisTech, Thiverval-Grignon, France

${ }^{6}$ Institute of Ecology and Environmental Sciences of Paris (UMR 7618), Universite Pierre et Marie Curie Paris06 Sorbonne (UPEC, UPMC, CNRS, IRD, INRA, Paris Diderot), 7 quai Saint Bernard, 75005, Paris, France Trento, Italy

${ }^{8}$ ECHO-EPFL, Laboratory of Ecohydrology, Ecole Polytechnique Fédérale de Lausanne, Lausanne, Switzerland

*Email: irene.criscuoli@gmail.com, tel. +39 0461 615389, fax. +390461650183

\section{Abstract}

\section{Background and Aims}

Soil incorporation of charcoal (biochar) has been suggested as practice to sequester carbon, improve soil properties and crop yields but most studies have been done in the short term. Old anthropogenic charcoal-rich soils in the Alps enable to explore the long-term impact of charcoal addition to alpine grassland on seed germination, fertility and fodder nutritive value.

Methods

A germination test and a growth experiment in pots with Festuca nigrescens Lam. and Trifolium pratense L. were performed using three different substrates: control soil (i.e. sandy-loam brown acid soils with some podsolization), charcoal hearth soil (i.e. charcoal-enriched anthropogenic soils derived from the carbonization of larch wood on flat terraces) and control soil mixed with a fraction of fresh larch wood charcoal to reach the soil-charcoal ratio of 0.6.

38 Both aged and fresh charcoal improved germination and markedly increased plant growth of the two plant species. The addition of fresh charcoal had an initial detrimental effect that disappeared in the second and third growth cycles. Plant 
41 and freshly amended soils demonstrating that biochar aging is critical to obtain a significant growth stimulation. Plant nutrient contents revealed an improved fodder quality in both the charcoal amended soils.

Conclusions

Despite the occurrence of limited toxic effects on seedlings, larch wood charcoal appears to have positive effects on fertility and fodder quality of alpine grasslands in the long term.

\section{Keywords:}

49 biochar, charcoal, alpine grasslands, fertility, N:P ratio, fodder nutritional value

\section{Acknowledgments}

The authors would like to thank the Stelvio National Park for allowing sampling campaigns; Ce.Spe.Vi. s.r.l.,

53 Pistoia for the experiment in the greenhouse; Dr. Luisa Andrenelli and Dr.Adriano Baglio (DISPAA Dipartimento di

54 Scienze delle Produzioni Agroalimentari e dell'Ambiente - University of Florence) for laboratory analysis; Roberta

55 Franchi (Fondazione Edmund Mach) for her important advise on alpine pastures and meadows management and the

56 Italian Biochar Association (ICHAR). 
Alpine grasslands are considered critical biodiversity hotspots (Väre et al. 2003) providing a series of ecosystem services (Fontana et al. 2013) and sustaining the production of typical food resources with added value (Bovolenta et al. 2011). The persistence of these semi-natural ecosystems is based on ancient and specific management techniques adapted to the local needs ensuring their productivity for thousands of years (Poschlod and Wallisdevries 2002) and the accumulation of one of the highest soil carbon stock (Gamper et al. 2007; Ciais et al. 2010). Traditional management techniques include intense land uses based on different stocking rates (different breeds and grazing period lengths), mowing frequency, organic and inorganic fertilization (Maurer 2005), periodic re-sowing (Tozer et al. 2013) and more rarely irrigation (Riedener et al. 2013). Major threats to these ecosystems arise from climate change, land abandonment and inadequate intensification. In particular, abandonment has substantially reduced the surface area occupied by mountain grasslands throughout Europe (Tasser et al. 2007), mainly leading to the expansion of secondary forests (Tasser and Tappeiner 2002). Inadequate management techniques are instead increasing the risks of soil erosion, landslides and avalanches (Tasser et al. 2003), often causing the diffusion of unpalatable plant species (Krahulec et al. 2001), loss of biodiversity (Dullinger et al. 2003), decreasing touristic attractiveness (Hunziker 1995) and, in some instances, the loss of important soil organic carbon stocks (Poeplau and Don 2013). In the context of these changes, appropriate management of mountain pastures and meadows is becoming a societal priority that should be based on novel techniques ensuring the socio-economic viability of mountain communities, the conservation of their beauty as well as their ecosystem services.

The use of biochar, a carbon rich co-product of pyrolysis, as soil amendment is currently receiving a lot of attention as it can improve the physico-chemical properties of soils, reduce nutrient leaching (Glaser et al. 2001), increase water infiltration and water holding capacity (Lim et al. 2016; Novak et al. 2016), enhance cation exchange capacity (Liang et al. 2006), soil aeration (Case et al. 2012), thus stimulating biomass yields (Jeffery et al. 2011; Biederman and Harpole 2012). Moreover, because of its substantial recalcitrance to microbial degradation, biochar application to soil is also considered as an effective way to sequester atmospheric carbon (Lehmann et al. 2006; Sohi et al. 2009; Criscuoli et al. 2014; Wang et al. 2015). On the other hand, the use of biochar as a soil amendment entails also some risks which are not yet fully understood (Kuppusamy et al. 2016). In fact, biochar can be a source of toxicants such as polycyclic aromatic hydrocarbon (PAHs) (Kloss et al. 2012), can retain heavy metals, can suppress the efficacy of applied pesticides and may induce changes in soil microbial community composition and structure (Jenkins et al. 2016) with possible influence on the microbial-mediated transformation of nutrients. Moreover, its role in offsetting C and the other greenhouse gases' emissions has been questioned because of the possible priming effect on the native soil organic matter (Ventura et al. 2015; Fang et al. 2015), the induced changes in the surface albedo (Genesio et al. 2012) and the possible associated $\mathrm{C}$ aerosol emissions (Genesio et al. 2016).

The large majority of studies involving biochar applications, including those made on lowland grasslands (Van de Voorde et al. 2014; Schimmelpfennig et al. 2014; Schimmelpfennig et al. 2015), are based on short-term experiments, mostly made immediately after biochar application. Only the work of Hernandez-Soriano et al. (2015) showed that 150 years old charcoal kiln areas located in agricultural fields were still able to increase the productivity of maize (+10\%). As biochar properties were shown to change with time of exposure (i.e. ageing), in particular through surface oxidation (Liang et al. 2006), short-term studies may be insufficient to assess its impact on soil fertility in the long-term. The productivity of mountain grassland ecosystems is the result of a complex set of interactions between grazing pressures and nutrients export, plant species composition and the establishment of soil microorganisms and soil 
micro-fauna communities, which are related to specific functional traits, whose dynamics necessarily require long-term studies (Grigulis et al. 2013).

To properly address this critical issue, this paper assesses the effects of 158 years old anthropogenic charcoal rich soils (Criscuoli et al. 2014), derived from carbonization of larch wood (Larix decidua L.) on flat terraces (Backmeroff 2013), on germination, growth and nutritive value of a typical grass and mountain leguminous species (Festuca nigrescens Lam. and Trifolium pratense L. subsp. nivale (Koch)) in comparison to native (control) soil and control soil amended with fresh biochar derived from larch wood. The presence of multiple charcoal rich soils gave us the opportunity to work on a fully replicated scheme, to be considered as an analogue of a deliberate centennial timescale application of biochar to a mountain grassland soil. The hypothesis is that plant productivity and nutritional value of both plant species, and especially of $T$. pratense, are higher in charcoal hearth soils compared to control soils and to soils amended with fresh larch charcoal because of char ageing (Pusceddu et al. 2013). The effects on seeds germination are expected to be less evident.

\section{Materials and methods}

\section{Study site, soil sampling and charcoal production}

Several charcoal-enriched anthropogenic soils (charcoal hearths) derived from the carbonization of larch (Larix decidua L.) wood on flat terraces, dating back to between 1500 and 1858 (Backmeroff 2013), were identified in Val di Pejo (Trentino, Northern Italy) at an altitude of $2150 \mathrm{~m}$ a.s.1., in a larch alpine grassland grazed in summer. A complete description of the site, soil characteristics and historical charcoal production can be found in Criscuoli et al. (2014). In brief, the charcoal hearths' soils are made of a surface organic horizon $(\sim 2 \mathrm{~cm})$ and a thicker black anthropogenic layer $(20 \mathrm{~cm})$ rich in charcoal residues left after the carbonization 158 years ago and today well mixed with the pre-existing soil layer. The control soils are sandy-loam brown acid soils with some podsolization (Lithic Dystrudept and Entic Haplorthod) (Smith and Atkinson 1975). Both control and hearths' soils have a pH of 5.1. The hearths' soils are very rich in carbon $\left(26.2 \pm 5.3 \mathrm{~kg} \mathrm{C} \mathrm{m}^{-2}\right), 90 \%$ of which is contained in the charcoal, and are also richer in nutrients than the surrounding control soils (Tab. 1).

Three paired sites (i.e. charcoal hearth and native soil as control) were selected on the basis of common aspect (SE) and conservation state (no significant geo-morphological dynamics or recent anthropogenic disturbances). In September 2014, 20 L of soil were sampled with shovels from the center of the three hearths and in the corresponding adjacent control areas, after removing the top organic layer.

Fresh charcoal was produced from larch wood at $450^{\circ} \mathrm{C}$, the average temperature occurring in traditional carbonization wood piles (FAO 1987). Fragments of larch wood were carefully wrapped in Aluminum foil and placed in a preheated muffle furnace at a temperature of $450{ }^{\circ} \mathrm{C}$ for 10 minutes. The carbon content of the freshly produced charcoal was $76 \pm 7 \mathrm{gC} \mathrm{kg}^{-1}$, the nutrient composition is reported in the Tab. 1 and the specific surface area (total BET) was $239.5 \mathrm{~m}^{2} \mathrm{~g}^{-1}$.

\section{Germination test}

Seeds of Festuca nigrescens Lam. and Trifolium pratense L. subsp. nivale (Koch) were obtained from a nursery. Total germination and germination rates for each species were assessed through a test in petri dishes. Three different substrates were considered: control soil $(\mathrm{C})$, charcoal hearth soil $(\mathrm{H})$ and control soil mixed with a fraction of 
fresh larch wood charcoal (CC) to reach the soil-charcoal ratio of 0.6 equivalent to a charcoal dose of $39 \mathrm{~kg} \mathrm{~m}^{-2}$, which was estimated as the initial char input at the three charcoal hearths 158 years ago (Criscuoli et al. 2014). 54 dishes were prepared ( 2 species x 3 soil types x 3 sampling areas x 3 replicates). In each petri dish, 10 seed of one species were sown and dishes were maintained in the dark. Germination was determined when the coleoptile was $\geq 2 \mathrm{~mm}$ for $F$. nigrescens and when the two cotyledons were visible and free from the seed coat for T. pratense.

\section{Growth experiment}

The three soil types were also used as substrates for a plant growth experiment in small pots of $135 \mathrm{~cm}^{3}$. Prior to sowing, the pots were left for two months in a greenhouse with regular irrigation in order to allow the seeds contained in the seed bank to germinate spontaneously. Naturally germinated plants were then periodically removed manually. To eliminate possible confounding effects due to differences in the soil temperature, caused by different light reflection/absorbance properties (albedo), the soil surface of each pot was covered with an uniform thin layer of black inert quartz granules of $1.5 \mathrm{~mm}$ diameter (Granulati Zandobbio, Bergamo). The plants were grown in monoculture for a total of 144 pots ( 2 species x 3 soil types x 3 sampling areas x 8 replicates). Seeds were sown at an initial density of 20 seeds $\operatorname{pot}^{-1}$ on $7^{\text {th }}$ January 2015 and the pots were stored on trays in a greenhouse, following a fully randomized experimental design. Air temperature and light in the greenhouse were left to fluctuate following external conditions, however temperature never dropped below $15^{\circ} \mathrm{C}$ by means of an automated heating system, while a minimum day length of 12 hours was ensured using artificial illumination during the winter months. Soil temperature was regularly checked at $3 \mathrm{~cm}$ depth using a digital thermal probe (109SS-L, Campbell scientific, Inc.) and no significant difference was observed among the soil treatments.

Nebulized irrigation provided water automatically at regular intervals, four times a day. Seven weeks after sowing, plant density was reduced to six plants per pot. Subsequently, three growth cycles were considered with complete aboveground biomass harvest made 17 ( $1^{\text {st }}$ cycle $), 22$ ( $2^{\text {nd }}$ cycle $)$ and 30 weeks $\left(3^{\text {rd }}\right.$ cycle $)$ after sowing. At each harvest, the plants were oven dried at $80^{\circ} \mathrm{C}$ for 48 hours and weighed. At the end of the $3^{\text {rd }}$ cycle, the roots were manually separated from the soil, washed and dried for 48 hours at $80^{\circ} \mathrm{C}$ and weighed.

\section{Plant, charcoal and soil physico-chemical analysis}

Plant, soil and charcoal samples were dried and finely ground prior to analysis.

Isotopic ratios were determined with an Isotope Ratio Mass Spectrometer (Thermo Fischer Scientific, Delta V Plus). Natural abundances of stable carbon $\left(\delta^{13} \mathrm{C}\right)$ and nitrogen $\left(\delta^{15} \mathrm{~N}\right)$ isotopes were measured for both plant species and the fine soil fraction $(<2 \mathrm{~mm})$ of hearth and control soils as well as for both the ancient and the freshly produced charcoal fragments. The carbon isotope discrimination $(\Delta)$ was then calculated according to Farquhar and Richards (1984):

$$
\Delta=\frac{\delta_{a}-\delta_{p}}{1+\delta_{p}}
$$

where $\delta_{\mathrm{a}}$ is the $\delta^{13} \mathrm{CO}_{2}$ in the air and $\delta_{\mathrm{p}}$ is that of plant carbon.

Total $\mathrm{Ca}^{2+}, \mathrm{K}^{+}, \mathrm{Mg}^{2+}, \mathrm{Na}^{+}, \mathrm{P}, \mathrm{Cu}, \mathrm{Fe}$ were determined on oven-dried plant subsamples $\left(105^{\circ} \mathrm{C}\right.$ for $\left.24 \mathrm{~h}\right)$ from the second harvest, according to the EPA method 3052 (USEPA 1996) using an ICP-OES spectrophotometer (Varian 
Inc., Vista MPX). Total carbon and nitrogen concentrations were determined via total combustion in an elemental analyzer (EA Flash 1112 ThermoFinnigan).

Soil and charcoal $\mathrm{pH}$ were measured in a soil-charcoal/distilled water solution (1:4 ratio as reported in Di Lonardo et al. 2013; Vaccari et al. 2015).

The surface area of fresh charcoal was calculated by using the BET (Brunauer-Emmet-Teller) method and Langmuir method applied to nitrogen adsorption data in the relative pressure $\left(\mathrm{P} / \mathrm{P}^{\circ}\right)$ range of $0.1-0.44$.

\section{Statistical analyses}

Data were analyzed using R (version 2.15.3). The effects of the 3 treatments $(\mathrm{C}, \mathrm{H}$ and $\mathrm{CC}$ ) and of the 3 blocks ( 3 charcoal hearths and 3 control soils) were analyzed by a two-way ANOVA for each plant species. Individual comparisons were based on the Tukey's HSD post-hoc test. The data were checked for normality and homogeneity of variances by inspection of the residuals vs. fitted values and the Normal Q-Q plot. When data did not fulfill these requirements, they were $\log$-transformed or square root-transformed. In the case of negative data $\left(\delta^{13} \mathrm{C}\right)$, the data were standardized. Germination rates were compared using a binomial test (test for equality of proportions). The p-values of individual comparisons were corrected with the Holm method. All data in the text, figures and tables are reported as mean \pm standard deviation, if not differently stated.

\section{Results}

\section{Germination test}

Plants started to germinate after 96 hours of incubation. The percentage of germinated seeds after 96 and 120 hours from sowing was higher in $\mathrm{CC}$ compared to $\mathrm{C}$ and $\mathrm{H}$ both for F. nigrescens and T. pratense (Tab. 2), while early germination rates were similar or the same in $\mathrm{C}$ and $\mathrm{H}$. Looking at the total number of germinated plants, almost all seeds germinated in all soil types (between 78 and 94\%). The plant germination rates at the end of the experiment for both plants species were higher in both $\mathrm{CC}$ and $\mathrm{H}$ than in $\mathrm{C}$ (F. nigrescens: $\mathrm{CC}$ vs. $\mathrm{C}+14 \%, \mathrm{p}=0.08$ and $\mathrm{H}$ vs. $\mathrm{C}+13 \%$, $\mathrm{p}=0.09 ;$. pratense: $\mathrm{CC}$ vs. $\mathrm{C}+13 \%, \mathrm{p}=0.05$ and $\mathrm{H}$ vs. $\mathrm{C}+12 \%, \mathrm{p}=0.07)$.

\section{Plant growth}

At the end of the first growth cycle (week 1-17), both plant species grew more in H than in C and CC (Fig. 1) and the lower growth observed in the $\mathrm{CC}$ was highly statistically significant if compared to both $\mathrm{H}$ and $\mathrm{C}$. The relative changes in plant biomass in comparison to $\mathrm{C}$ were $+21,+9 \%$ for $\mathrm{H}$ and $-35,-71 \%$ for $\mathrm{CC}$, for T. pratense and $F$. nigrescens, respectively. The mean plant growth rate (MGR) was much lower in CC (T. pratense: $1 \mathrm{mg} \mathrm{day}^{-1}$ pot $^{-1} ; F$. nigrescens: $1.5 \mathrm{mg} \mathrm{day}^{-1}$ pot $\left.^{-1}\right)$ than in $\mathrm{C}\left(\right.$. pratense: $2.3 \mathrm{mg} \mathrm{day}^{-1}$ pot $^{-1} ; F$. nigrescens: $3.2 \mathrm{mg} \mathrm{day}^{-1}$ pot $\left.^{-1}\right)$ and $\mathrm{H}(T$. pratense: $2.8 \mathrm{mg} \mathrm{day}^{-1} \operatorname{pot}^{-1} ;$ F. nigrescens: $\left.3.5 \mathrm{mg} \mathrm{day}^{-1} \operatorname{pot}^{-1}\right)$.

At the end of the second growth cycle, biomass was again significantly higher in $\mathrm{H}$ than in $\mathrm{C}$ and $\mathrm{CC}$ for both species (Fig. 1). T. pratense and F. nigrescens plants grown on $\mathrm{H}$ produced almost 3 and 1.5 times more than on $\mathrm{C}$, respectively. Plants grown on CC performed better than on the control soil (both T. pratense, F. nigrescens $=+37 \%$ ), even though the difference was significant only in the case of $T$. pratense $(\mathrm{p}=0.01)$. MGR was accelerated compared to the first cycle and rose to 10.7 and $41.1 \mathrm{mg} \mathrm{day}^{-1}$ pot $^{-1}$ for $T$. pratense and to 16.6 and $40.7 \mathrm{mg} \mathrm{day}^{-1}$ pot $^{-1}$ for $F$. nigrescens grown in $\mathrm{C}$ and $\mathrm{H}$, respectively. 
Similarly to the second cycle, at the end of the third cycle plant biomass was significantly higher in $\mathrm{H}$ than in the other two treatments (Fig. 1). F. nigrescens plants grown on $\mathrm{H}$ produced almost 1.5 times more than plants grown on $\mathrm{C}$ and T. pratense 0.6 times more. Plants grown on $\mathrm{CC}$ performed better than on $\mathrm{C}$ ( F. nigrescens $=+51 \%, T$. pratense $=+22 \%$ ) even though the difference was significant only in the case of $F$. nigrescens $(\mathrm{p}=0.01)$. The MGR decreased compared to the second cycle to 24.1, 9.9 and $15 \mathrm{mg} \mathrm{day}^{-1}$ pot $^{-1}$ for F. nigrescens and to 19.1, 12.1 and 14.9 mg day ${ }^{-1}$ pot $^{-1}$ for $T$. pratense grown in $\mathrm{H}, \mathrm{C}$ and $\mathrm{CC}$, respectively.

Overall, the total amount of biomass produced over the three cycles (above and belowground) was $88 \%$ and $108 \%$ higher in $\mathrm{H}$ compared to $\mathrm{CC}(\mathrm{p}<0.001)$ and $114 \%$ and $148 \%$ higher in $\mathrm{H}$ compared to $\mathrm{C}(\mathrm{p}<0.001)$ for $F$. nigrescens and $T$. pretense, respectively (Fig. 2). Total biomass was slightly higher in CC compared to $\mathrm{C}$ for both plant species, but the differences were not significant $(F$. nigrescens: $\mathrm{p}=0.29$, T. pretense: $\mathrm{p}=0.25$ ).

The root:shoot ratio, was significantly higher for $T$. pratense plants grown on $\mathrm{H}$ than $\mathrm{C}(\mathrm{p}=0.02)$, while for $F$. nigrescens no differences in the ratio were detected among treatments (Fig. 3).

\section{Soil and plant nutrients}

The content of $\mathrm{Ca}^{2+}, \mathrm{Mg}^{2+}, \mathrm{Na}^{+}$and $\mathrm{P}\left(\mathrm{mg} \mathrm{g}^{-1}\right)$ in the plants tissues (Tab. 3) was the highest in F. nigrescens and $T$. pratense grown on $\mathrm{H}$ followed, in most cases, by plants grown on CC. The differences in the nutrient content of T. pratense between $\mathrm{H}$ and $\mathrm{C}$ were significant at $\mathrm{p}=0.10$ for all the nutrients, while no significant differences between $\mathrm{H}$ and $\mathrm{CC}$ in $T$. pratense and among all treatments for $F$. nigrescens were detected (Tab. 3). The $\mathrm{K}^{+}$content of $T$. pratense was higher in plants grown on $\mathrm{H}$ ( $\mathrm{H}$ vs. $\mathrm{CC}$ : $\mathrm{p}=0.18$; $\mathrm{H}$ vs. $\mathrm{C}$ : $\mathrm{p}=0.06$ ), but for $F$. nigrescens plants it was higher when plants were grown on $\mathrm{CC}$, even though not significantly. An opposite trend was observed for $\mathrm{N}$, which was higher for plants grown on $\mathrm{C}$ for both species, followed by $\mathrm{CC}$ and $\mathrm{H}$. Fe content showed a very high variability in plants grown on the same soil type, while soil $\mathrm{Cu}$ content was very similar for all the three treatments. The nutrient content of $T$. pratense was usually higher than that of $F$. nigrescens with the exception of $\mathrm{P}$ that was higher for $F$. nigrescens plants when grown on $\mathrm{H}$ and $\mathrm{C}$.

The N:P ratio of $F$. nigrescens and T. pratense plants grown on $\mathrm{H}$ was 10.4 and 10.7, respectively, while plants grown on $\mathrm{C}$ showed a ratio of 18.3 and 21.5 and plants grown on $\mathrm{CC}$ soils 23.3 and 16.3 (Fig. 4).

Soil nutrient content data were taken from Criscuoli et al. (2014) and are here reported in the Tab. 1. The soil $\mathrm{N}: \mathrm{P}$ ratio in soil was 13.3, 5.7 and 11 in $\mathrm{C}, \mathrm{H}$ and CC, respectively (Fig. 4).

Plant $\mathrm{P}$ concentration increased with increasing soil concentration. The highest values were observed for the $\mathrm{H}$ soil and in the plants grown on it, while soil and plants grown on $\mathrm{CC}$ and $\mathrm{C}$ gave very similar results (Fig. 5). Plant $\mathrm{K}^{+}$ concentration correlated positively with the soil nutrient contents. Concentrations of both soils and plants decreased in the order $\mathrm{H}>\mathrm{CC}>\mathrm{C}$ (Fig. 5). We observed a similar behavior for $\mathrm{Ca}^{2+}$ in the case of T. pretense, while the content of $F$. nigrescens was insensitive to the soil content variations (Fig. 5). $\mathrm{Na}^{+}$content was the lowest for $\mathrm{H}$ soils. The concentration of the plants tissues decreased for $T$. pratense with increasing soil concentrations, while values observed for F. nigrescens did not reflect the $\mathrm{Na}^{+}$soil content (Fig. 5). $\mathrm{Mg}^{2+}$ concentration of the soil was not reflected in the content of plants for both species. The $\mathrm{Mg}^{2+}$ content of T. pratense was double compared to F. nigrescens (Fig 5, Tab. 1 and Tab. 3).

Isotopic signature 
The ${ }^{13} \mathrm{C}$ discrimination $(\Delta)$ at the end of the first growth cycle was significantly higher for $F$. nigrescens and $T$. pratense plants grown on $\mathrm{CC}$ ( 24.5 and $23.6 \%$, respectively) than on $\mathrm{C}(21.8 \%$ with $\mathrm{p}=0.0006$ and $22.1 \%$ with $\mathrm{p}=0.051)$ and $\mathrm{H}(21.5 \%$ with $\mathrm{p}=0.0004$ and $22.1 \%$ with $\mathrm{p}=0.051)$.

At the end of the second growth cycle, the $\Delta$ of both plant species grown on $\mathrm{H}$ and $\mathrm{C}$ slightly increased in comparison with the first one (T. pratense: $\mathrm{H}+0.74 \%, \mathrm{C}+0.42 \%$; F. nigrescens: $\mathrm{H}+1.02 \%, \mathrm{C}+0.56 \%$ ), while, when they were grown on CC, the $\Delta$ decreased (T. pratense: $-0.56 \% ; F$. nigrescens: $-1.55 \%$ ) to similar values for both species $(22.99 \%)$ and to the other two soil treatments. At the third harvest, plants showed smaller $\Delta$ values and no differences among treatments (Fig. 6).

At the end of the first growth cycle, the $\delta^{15} \mathrm{~N}$ was very similar for $T$. pratense and $F$. nigrescens plants grown on $\mathrm{C}$ soils (6.9 and 7\%o, respectively). The isotopic signature of plants grown on $\mathrm{H}$ was lower and very similar for the two plant species as well (T. pratense: $4.9 \%$; F. nigrescens: $5.1 \%$ ). Similar data were observed at the end of the second growth cycle (T. pratense C: 6.5\%, H: 4.8\%; F. nigrescens C: 6.4\%, H: 5.8\%), while, at the third harvest, the isotopic signature rose in both species and became slightly higher for plants grown on $\mathrm{H}$ as compared to those grown on $\mathrm{C}$ ( $\mathrm{T}$. pratense C: 7.2\%, H: 7.7\%; F. nigrescens C: 7.1, H: 7.3\%; Fig. 7). A very different trend was observed for plants grown on CC where, at the end of the first growth cycle, $T$. pratense plants showed a $\delta^{15} \mathrm{~N}$ of $-0.07 \%$, much lower than the other treatments, especially compared to $\mathrm{C}(\mathrm{CC}$ vs. $\mathrm{H} \mathrm{p}=0.19$; $\mathrm{CC}$ vs. $\mathrm{C} \mathrm{p}=0.08)$. F. nigrescens had a $\delta^{15} \mathrm{~N}$ equal to $3.3 \%$ ( $\mathrm{CC}$ vs. $\mathrm{H} \mathrm{p}=0.24$; $\mathrm{CC}$ vs. $\mathrm{C} \mathrm{p}=0.04$ ). After the second growth cycle, the isotopic signature of both $T$. pratense and $F$. nigrescens increased (1.4\% and 4.8\%, respectively), but did not equal the values observed for the other two soil treatments (T. pratense: $\mathrm{CC}$ vs. $\mathrm{H} \mathrm{p}=0.06, \mathrm{CC}$ vs. $\mathrm{C} \mathrm{p}=0.02 ;$ F. nigrescens: $\mathrm{CC}$ vs. $\mathrm{H} \mathrm{p}=0.25, \mathrm{CC}$ vs. $\mathrm{C} \mathrm{p}=0.07$ ). The $\delta^{15} \mathrm{~N}$ of both species increased also during the third growth cycle (T. pratense: 5.3\%o and F. nigrescens: 5.8\%o), getting closer to the signature measured in the other treatments (ranging between 7.1 and 7.7\%; Fig. 7).

The control soil had a $\delta^{15} \mathrm{~N}$ equal to $3.9 \pm 1.3 \%$, markedly higher than $\mathrm{H}(2.1 \pm 1.1 \%)$, while the ancient and the freshly produced charcoal had very similar $\delta^{15} \mathrm{~N}$ signatures $(1.1 \pm 1.6 \%$ and $0.9 \pm 0.2 \%$, respectively).

\section{Discussion and conclusions}

The three substrates had differential effects on germination. For both plant species, early germination rates were higher in the control soils amended with fresh charcoal (CC) than in hearths soils (H) and control soils (C). Moreover, the total number of germinated seeds 10 days after sowing was stimulated for both species by the presence of old (H) and fresh charcoal (CC) amendment (Tab.2). Previous research on T. pratense by Van de Voorde et al. (2014) found no effect of biochar addition to the soil substrate on the germination and Solaiman et al. (2011) found a dosedependent negative germination effect on another Trifolium species. In contrast, we did not observe any inhibitory effect on seeds germination, but a tendency to an increase in germination in the presence of both fresh and old charcoal. These positive effects could be related to the presence of specific compounds such as karrikins, a family of butenolides, which are known to be contained in charcoal (Flematti et al. 2008; Nelson et al. 2012). Karrikins act as germination stimulants and have been recently isolated, identified (Flematti et al. 2004) and successfully synthesized (Flematti et al. 2011) even though the mechanisms by which they might trigger seed germination are far from being completely described. Another possible mechanism explaining the higher germination rates in $\mathrm{CC}$ and $\mathrm{H}$ could be related to the ability of charcoal to adsorb biogenic phyto-toxins eventually present into the soil (Garnett et al. 2004; Hille and Den Ouden 2005). 
In the pot experiment, at the end of the first growth cycle, both species grew better on $\mathrm{H}$ than on $\mathrm{C}$ and $\mathrm{CC}$ (Fig. 1). Reduced growth on $\mathrm{CC}$ was remarkable and attributable to a stress effect caused by the addition of fresh char. Such a stress caused a decrease in the photosynthetic capacity of plant leaves, which was reflected in an increase in their $\Delta \Delta^{13} \mathrm{C}$ (Fig. 6) (Brugnoli et al. 1989). A possible source of stress affecting plant growth on CC could have been the difference in the $\mathrm{pH}$ between the fresh larch charcoal $(\mathrm{pH}=7.1)$ and the control soil to which it was added to $(\mathrm{pH}=5.1)$. Soil alkalization is known to have detrimental effects on plants as high $\mathrm{pH}$ generally causes metal ions to precipitate, thus affecting the absorption of inorganic ions and disrupting the ionic balance of tissues (Chen et al. 2009). In our case, the bulk soil $\mathrm{pH}$ of $\mathrm{CC}$ rose to 5.8 and we cannot exclude that plant roots were in direct contact with charcoal fragments with a higher pH. However, 7.1 is a value close to neutrality and, moreover, Gell et al. (2011) did not find a clear relationship between $\mathrm{pH}$ and short-term phyto-toxicity on lettuce, radish and wheat plants. Thus, the toxic effect observed in the first growth cycle is very likely not to be linked to a $\mathrm{pH}$ stress. On the contrary, there could be a direct phytotoxic effect of charcoal on plant growth, both on germination and root and shoot growth as observed in previous studies that related the phyto-toxicity to the presence of chemicals in the biochar. For example, Rombolà et al. (2015) made the hypothesis that the phyto-toxicity was due to $\mathrm{NH}_{3}$, Volatile Fatty Acids and Benzoic acids contained in the charcoal, while Gell et al. (2011) associated the toxic effect of different kinds of biochar with their high water-soluble salts content, such as Chloride and Sodium, and possibly aliphatic and aromatic hydrocarbons such as phenols.

Observations made during the first growth cycle have important implications regarding the possibility of using biochar as a soil amendment in the framework of mountain pastures and meadows management and restoration. The data showed that while long-term exposure of pyrogenic carbon in soil, as occurred in $\mathrm{H}$, buffers any possible toxic effect, the sudden addition of biochar could have detrimental effects on plant growth. Even if the exact temporal dynamics of the transition between toxic and non-toxic conditions following biochar incorporation remains unknown, these data already suggest that the negative effect of charcoal incorporation into the soil is transitory as better environmental conditions certainly develop during biochar ageing. Moreover, transitory toxic effects can be avoided if is a) washed with water or an organic solvent, b) degraded via a biological activity through composting or mixing it with activated sludge (Bargmann et al. 2013; Rombolà et al. 2015) or c) dried at temperatures between 100 and $300^{\circ} \mathrm{C}$ for 24 hours (Kołtowski and Oleszczuk 2015) before being amended to soil. It is also likely that lower doses than used in the present experiment, could reduce detrimental effects on the plant growth, even in the very early stages.

The hypothesis of a transitory toxic effect of biochar on plant growth is also confirmed when looking at biomass production during the second and the third growth cycles (Fig.1). In fact, at the end of the second cycle, biomass was again significantly higher for plants grown on $\mathrm{H}$ compared to those grown on C. T. pratense plants grown on $\mathrm{H}$ produced almost threefold if compared to $\mathrm{C}$ and F. nigrescens 1.5-times more. On the other hand, conversely to what was observed in the first cycle, plants grown on CC performed better than those grown on $\mathrm{C}$ (both T. pretense and F. nigrescens $=+37 \%$ ). The recovery of both species grown in $\mathrm{CC}$ was also confirmed by the $\Delta^{13} \mathrm{C}$, which was not significantly different from the other two treatments (Fig. 6). The mean plant growth rate measured for plants grown on $\mathrm{H}$ was 4 and 3 times higher than those of plants grown on $\mathrm{C}$ for T. pratense and F. nigrescens and 2 and 3 times higher compared to those grown on CC, respectively, indicating a clearly higher fertility in charcoal hearths soils than in their natural counterparts and soils with fresh biochar. Similar results were obtained by Naisse et al. (2014), who observed much higher (micro-)biological activity in charcoal hearths as compared to control soils without ancient charcoal. The 
nutrients, their higher plant availability as well as improved physical characteristics of charcoal hearth soils compared to control (Criscuoli et al., 2014, Tab. 1).

Similarly to the second cycle, also at the third harvest, plant biomass was significantly higher for $\mathrm{H}$ than for the other two treatments (Fig. 1). However, the biomass measured for T. pratense grown on $\mathrm{H}$ at the end of the third cycle was lower in comparison to the second one. This could be due to the higher temperatures registered during the third growth cycle (summer) compared to the second one (spring), which caused the spread of necrotic tissues in the leguminous species (data not shown).

Overall, the total plant biomass produced over the three cycles (above and belowground) was significantly higher when plants were grown on $\mathrm{H}$ compared to $\mathrm{CC}$ and $\mathrm{C}$ both for $F$. nigrescens and $T$. pratense (Fig. 2). No significant differences were detected between plants grown on $\mathrm{CC}$ and $\mathrm{C}$, making the positive impact of charcoal on the long term productivity of alpine grasslands even more evident than the results of one single growth cycle.

The root:shoot ratio, a widely used indicator of plants health, gave differential results according to the species. It was significantly higher for $T$. pratense plants grown on $\mathrm{H}$ than for those grown on $\mathrm{C}$, while for F. nigrescens no difference in the ratio was detected among treatments (Fig. 3). The different behavior between the two species is related to the high interspecific variation in root:shoot ratios as reported by Koerner \& Renhardt (1987). The results observed for T. pratense seem to be in contrast with previous literature. In fact, for another species of clover (Solaiman et al. 2012), inconsistent effects of biochar on root:shoot ratio were observed. At high application rates charcoal had a negative effect. Moreover, it is known that the development of the root compartment may be smaller compared to aboveground biomass in nutrient rich soils (Agren and Franklin 2003), but according to our results T. pratense had a much higher root to shoot ratio in $\mathrm{H}$ soil, which shows the highest nutrient contents, both total and available (Criscuoli et al., 2014, Tab. 1). A possible explanation of high root to shoot ratios for T. pratense grown on $\mathrm{H}$ may be that roots development was more driven by hormonal factors rather than nutrients concentration. In fact, an increase in ethylene production, a plant hormone with important implication for plant growth and development, has been previously observed from biochar and biochar-amended soil (Spokas et al. 2010).

Soil and plants nutrient contents provided useful information to further examine and interpret our results. The idea that the ratios of $\mathrm{N}, \mathrm{P}$ and $\mathrm{K}$ in plant tissues provides an indication of the relative availability of these nutrients in the soil has often been discussed since the Von Liebig's Law of the Minimum (Von Liebig 1840). Koerselman \& Meuleman (1996), among others, assumed that the N:P ratio of plant tissues is a reliable indicator of soil fertility and proposed, on the basis of a meta-analysis of experimental data, that N:P thresholds of plant tissues can be used as indicators of N-limitations $(\mathrm{N}: \mathrm{P}<14)$ or P limitations $(\mathrm{N}: \mathrm{P}>16)$ or their co-limitation $(14<\mathrm{N}: \mathrm{P}<16)$ to plant growth. Accordingly, plants of both $F$. nigrescens and $T$. pratense species grown on $\mathrm{H}$ soils can be considered mostly $\mathrm{N}$-limited (leaves $\mathrm{N}: \mathrm{P}$ ratios of 10.4 and 10.7, respectively), while they were P-limited when grown on $\mathrm{C}$ and $\mathrm{CC}$ soils (N:P ratios > 16; Tab. 3 and Fig. 4). Thus, the lower plant biomass production in $\mathrm{C}$ and CC could be related to a P-limitation. In fact, total and available P-concentrations of these soils were similar and about one third compared to that of $\mathrm{H}$ soils (Criscuoli et al., 2014; Tab. 1). The soil P concentration for C and CC was reflected in the plants concentration which was similar (Tab. 3 and Fig. 5), showing that P added via charcoal was available for plants. This has been previously demonstrated specifically for larch wood (Larix gmelinii Rupr.) charcoal produced at $400^{\circ} \mathrm{C}$ (available P: $42.7 \mathrm{mg} \mathrm{kg}^{-1}$ biochar) and for the larch seedlings grown on a mixture of sand larch biochar which had higher foliar P concentrations in the presence of higher rates of char (Makoto et al., 2011). Thus, the higher P content observed in the H soils and 
via charcoal addition. It has been shown that $\mathrm{P}$ availability in charcoal amended soils is enhanced also via an increased mycorrhizal colonization and a change in soil P fractionation (Graber et al., 2015). Moreover, charcoal hearth soils might have accumulated the $\mathrm{P}$ atmospheric depositions due to desert dust transport and atmospheric pollution (Bergametti et al. 1992) or dung released from cattle over the 158 years of exposure in soil.

The higher plant $\mathrm{N}: \mathrm{P}$ ratio observed in CC soils for F. nigrescens compared to T. pratense (Fig. 4) is due to the higher $\mathrm{N}$ content in $T$. pratense (19.2 vs. $14.2 \mathrm{mg} \mathrm{g}^{-1}$ in $F$. nigrescens), while $\mathrm{P}$ content is almost the same in the two species ( 0.9 vs. $0.8 \mathrm{mg} \mathrm{g}^{-1}$, respectively; Tab. 3). The higher $\mathrm{N}$ content of the leguminous species might be explained by its nitrogen fixing capacity and this is also confirmed by the lower $\delta^{15} \mathrm{~N}$ that we observed for plants grown on CC in the first and second growth cycle, much closer to the atmospheric value (0\%) as compared to F. nigrescens (Fig. 7). These results are in line with several previous studies reporting an increase in nitrogen fixation in biochar amended soils (Rondon et al. 2006; Ogawa and Okimori 2010; Güereña et al. 2015; Van Zwieten et al. 2015) which has been mainly related to a greater B, Mo and $\mathrm{P}$ avaliability. The $\delta^{15} \mathrm{~N}$ signature of $F$. nigrescens plants grown on CC was higher than the signature of $T$. pratense grown on the same soil, but was lower than the signature of plants of the same species grown on the other soil types along the three growth cycles. This might be explained by the uptake of nitrogen contained in the fresh charcoal fragments (De la Rosa and Knicker, 2011), as the nitrogen isotopic signature of charcoal fragments is close to $1 \%$, while control soils have a signature of $3.9 \pm 1.3 \%$.

Similar to $\mathrm{P}$, the concentration of $\mathrm{K}^{+}$in tissues of both plant species and of $\mathrm{Ca}^{2+}$ in $T$. pratense plants correlated positively with soil nutrient content (Fig. 5), with higher concentrations observed in the case of higher biomass production $(\mathrm{H}>\mathrm{CC}>\mathrm{C})$. Similar observations were made by Schimmelpfennig et al. (2015). Even if the $\mathrm{Ca}^{2+}$ content is much lower in $\mathrm{C}$ compared to $\mathrm{H}$ and $\mathrm{CC}$, it cannot be considered as limiting factor as its concentration is well above the critical deficiency levels (0.5-1.5 $\left.\mathrm{cmol}_{\mathrm{c}} \mathrm{kg}^{-1}\right)$ reported by Kopittke and Menzies (2007). The concentration of $\mathrm{Ca}^{2+}$ was doubled in the leguminous species compared to grass, in agreement with literature results (Juknevičius and Sabiené 2007).

$\mathrm{Na}^{+}$content of the plants did not reflect the concentration of the nutrient in the soil (Fig. 5). Sodium is toxic at high concentrations for most of the plant species (Greenway and Munns 1980), so the adsorption through the plant roots' cell is limited as much as possible by mechanisms of selective uptake and ion exclusions (Schachtman and Liu 1999). The behavior of $\mathrm{Na}^{+}$is opposite to what was observed for $\mathrm{K}^{+}$. The two ions are very similar for their ionic radius and ion hydration energies, factors determining their movement through the cell's membrane (Hille 1992), but the competition between the two ions in soils which are not saline is usually in favor of $\mathrm{K}^{+}$because it is not toxic. On the contrary, it is fundamental for plant growth of all species and it is the cation with the highest concentration in plant tissues (Mäser et al. 2002). As for $\mathrm{Ca}^{2+}$, the concentration of $T$. pratense plants is double, or more, compared to $F$. nigrescens even if $T$. pratense is less tolerant to salinity than F. nigrescens (FAO 2002). However $\mathrm{Na}^{+}$concentration in the leaves of $T$. pratense did not reach toxic levels, in fact no detrimental effects were observed on the plant growth.

Similarly to $\mathrm{Na}^{++}$, higher soil concentrations of $\mathrm{Mg}^{2+}$ did not correspond to any increase in the magnesium content in plant tissues. The concentrations of $\mathrm{Na}^{+}$and $\mathrm{Mg}^{2+}$ were lower $(\mathrm{H}<\mathrm{CC}<\mathrm{C})$ in the soils with elevated $\mathrm{K}^{+}$and $\mathrm{Ca}^{2+}$ concentrations $(\mathrm{H}>\mathrm{CC}>\mathrm{C})$. This may be related to the competition between cations given a certain cation exchange capacity of the soil. The fact that lower $\mathrm{Mg}^{2+}$ soil content was not reflected by a lower concentration in plants tissues might be seen as the evidence of a proper cations balance in the soil. As for $\mathrm{Na}^{+}$and $\mathrm{Ca}^{2+}, \mathrm{Mg}^{2+}$ content of T. pratense plants is twice than that of $F$. nigrescens and this is in line with previous works on these two plant species (Juknevičius and Sabiené, 2007). 
The micro- and macro-nutrient contents of pasture and meadow plants are fundamental for the quality of the fodder. The German Society of Nutritional Physiology, among others, provides specific recommendations at this regard (Flachowsky et al. 2001, Online Resource Tab. 1). In our experiment the P content of fodder improves when plants were grown on $\mathrm{H}$ compared to those grown on $\mathrm{C}$ and $\mathrm{CC}$ but did not fulfill the cattle requirements.

$\mathrm{K}^{+}$content of plants increased for both charcoal treatments compared to $\mathrm{C}$ where both plant species had lower concentrations than recommended. $\mathrm{K}^{+}$content in F. nigrescens was in line with recommendations when grown on $\mathrm{H}$ and $\mathrm{CC}$, while $\mathrm{K}^{+}$concentrations in $T$. pratense plants exceeded the recommendations when grown on $\mathrm{H}$. However, the value did not reach the limit of $\geq 35 \mathrm{~g} \mathrm{~kg}^{-1}$ dry biomass, which is considered to be the cause of the so called "grass tetany", a $\mathrm{Mg}^{2+}$ deficiency in ruminants which implies cattle to be fed with supplementary magnesium (Kessler, 2001). $\mathrm{Ca}^{2+}$ and $\mathrm{Mg}^{2+}$ concentrations were very high for both plant species grown on all soil types compared to the recommendations, especially for those grown on soils amended with charcoal and for T. pratense plants. But an adequate nutritive balance between $\mathrm{K}^{+}, \mathrm{Ca}^{2+}$ and $\mathrm{Mg}^{2+}$ was guaranteed, as the ratio $\mathrm{K}:(\mathrm{Ca}+\mathrm{Mg})$ was lower than 2.2 (Reid and Horvath 1980).

Fe measurements showed a large variability in our experiment so they have to be considered with caution, but it is clear that Fe content of plant tissues exceeded the recommendation in all treatments and species, with highest values for those grown on C. It is very common for pastures and meadows plants to exceed the iron supply recommendations for cattle and values up to $500 \mathrm{mg} \mathrm{kg}^{-1}$ are usually tolerated (Flachowsky et al. 2001). This threshold is only exceeded in the case of $F$. nigrescens plants grown on $\mathrm{C}$, showing that charcoal application has been beneficial.

$\mathrm{Na}^{+}$content was higher than recommended for $T$. pretense, especially when grown on soils amended with charcoal, but these concentrations are not considered harmful for cattle. The concentrations we found were lower than $2.5 \mathrm{~g} \mathrm{~kg}^{-1}$ Dry Matter (DM) (Tab. 3), while the maximum level of sodium tolerated in forage for dairy cattle is $15.73 \mathrm{~g}$ $\mathrm{Na} \mathrm{kg}^{-1}$ DM (Johansson 2008)

$\mathrm{Cu}$ was higher than recommended only for $T$. pratense plants but with no difference among the treatments. Chronic copper poisoning is possible in cattle with a dietary concentration of $40 \mathrm{mg} \mathrm{kg}^{-1}$ (National Research Council 2001), but this threshold was far from being reached in our samples with values around $17 \mathrm{mg} \mathrm{kg}^{-1}$ (Tab. 3).

Charcoal application to the alpine grasslands in this study, both in the short and in the long term $(\mathrm{CC}$ and $\mathrm{H})$, overall improved fodder quality in terms of $\mathrm{P}, \mathrm{K}^{+}$and $\mathrm{Fe}$ content compared to the control soils. $\mathrm{Ca}^{2+}, \mathrm{Mg}^{2+}, \mathrm{Na}^{+}$and $\mathrm{Cu}$ contents were found to be higher than recommendations in all treatments, including control, but they did not reach harmful levels, thus guaranteeing cattle health.

The positive results observed for charcoal amended soils in terms of germination, plant growth, root:shoot ratio and fodder quality, both directly after application and after ageing, support the idea that larch wood charcoal is a soil amendment suitable for alpine pastures and meadows even at an application rate of $390 \mathrm{t} \mathrm{ha}^{-1}$. From a management point of view, biochar incorporation into soil implies ploughing, a technique which is very rarely used in alpine management because of multiple factors: the soil layer is thin to bedrock, with very irregular profiles (Stanchi et al. 2012); ploughing will increase soil erosion which is already a main problem in mountain soils because of slope, soil depth, climate and soil low resilience which makes them almost no renewable (Tasser et al. 2003; Stanchi et al. 2012); most of the grasslands are located in areas very difficult to reach with machines that is needed for biochar spreading and incorporation into soil. Thus, biochar cannot be used for standard management, but can be helpful in the framework of abandoned pastures and meadows in the Alps is usually based on the manual removal of trees and invasive species, 
450 sometimes applying herbicides locally, and very rarely destroying the soil layer because of the reasons listed above 451 (Belleri 2014). For these reasons, biochar application is worth considering in cases of severely damaged grasslands (ski 452 tracks openings) or where the modifications to the environment have been so profound that the reconstitution of the 453 former ecosystem is no longer possible (roads or dumps construction) (Muller et al. 1998). However, possible impacts 454 on plant biodiversity remain to be explored and a deeper examination of nutrient cycles, microbial biodiversity and the 455 role played by hormones should be a research priority for next experiments in this unique environment to better 456 understand and quantify the overall impact of biochar application on nature conservation and the important ecosystem 457 services that mountain grasslands provide. 


\begin{tabular}{|l|c|c|c|c|}
\hline Element & Control soil & Charcoal hearth soil & Fresh char & Control soil + fresh char \\
\hline $\mathrm{Ca}$ & $993 \pm 233^{*}$ & $3301 \pm 321^{*}$ & $5909 \pm 86$ & $2870 \pm 150$ \\
& $(278 \pm 61)^{*}$ & $(1006 \pm 274)^{*}$ & & \\
\hline $\mathrm{K}$ & $1604 \pm 201^{*}$ & $2464 \pm 120^{*}$ & $2906 \pm 54$ & $2100 \pm 130$ \\
& $(147 \pm 52)$ & $(279 \pm 208)$ & & \\
\hline $\mathrm{Mg}$ & $2739 \pm 128$ & $2379 \pm 665$ & $1522 \pm 56$ & $2274 \pm 82$ \\
& $(80 \pm 21)^{*}$ & $(245 \pm 7)^{*}$ & & $264 \pm 54$ \\
\hline $\mathrm{Na}$ & $298 \pm 88^{*}$ & $93 \pm 15^{*}$ & $210 \pm 4$ & \\
& $(34 \pm 2)$ & $(33 \pm 45)$ & & $316 \pm 8$ \\
\hline $\mathrm{P}$ & $321 \pm 13^{*}$ & $921 \pm 357^{*}$ & $308 \pm 1$ & \\
& $(7 \pm 3)^{*}$ & $(12 \pm 7)^{*}$ & & $3480 \pm 870$ \\
\hline $\mathrm{N}$ & $4307 \pm 1402$ & $5189 \pm 1756$ & $2139 \pm 340$ & \\
\hline
\end{tabular}

461 Tab. 1 Total nutrient content $\left(\mathrm{mg} \mathrm{kg}^{-1}\right)$ in control soil, charcoal hearth soil, fresh char and control soil + fresh char at the beginning of the experiment. In parenthesis, data on available nutrient concentration $\left(\mathrm{mg} \mathrm{kg}^{-1}\right)$ for control and charcoal hearths soils are reported. Data for hearths, control soils and fresh charcoal are taken from Criscuoli et al. (2014), while data for the control soil + fresh charcoal are calculated. Asterisks indicate significant differences between control and charcoal hearth soils at $\mathrm{p} \leq 0.05$. 


\begin{tabular}{|c|c|c|c|c|}
\hline plant species & time & $\mathbf{C}$ & $\mathbf{C C}$ & $\mathbf{H}$ \\
\hline \multirow{3}{*}{ T. pratense } & 96 hours & $2 \mathrm{a}$ & $7 \mathrm{a}$ & $2 \mathrm{a}$ \\
\cline { 2 - 5 } & 120 hours & $18 \mathrm{ab}$ & $29 \mathrm{a}$ & $16 \mathrm{~b}$ \\
\cline { 2 - 5 } & 10 days & $83 \mathrm{a}$ & $94 \mathrm{~b}$ & $93 \mathrm{~b}$ \\
\hline \multirow{2}{*}{ F. nigrescens } & 96 hours & $6 \mathrm{a}$ & $13 \mathrm{a}$ & $6 \mathrm{a}$ \\
\cline { 2 - 5 } & 120 hours & $11 \mathrm{a}$ & $19 \mathrm{a}$ & $12 \mathrm{a}$ \\
\cline { 2 - 5 } & 10 days & $78 \mathrm{a}$ & $90 \mathrm{~b}$ & $89 \mathrm{~b}$ \\
\hline
\end{tabular}

468 Tab. 2 Germinated seeds (\%) of T. pratense and F. nigrescens after 96 and 120 hours and 10 days from sowing in control (C), control + fresh charcoal (CC) and charcoal hearth $(\mathrm{H})$ soils. Different letters indicate significant differences among soil treatments within each plant species and time frame at $\mathrm{p} \leq 0.10$. 


\begin{tabular}{|l|c|c|c|}
\hline \multicolumn{4}{|c|}{ Trifolium pratense } \\
\hline Element $\left(\mathbf{m g ~ g}^{-1}\right)$ & $\mathbf{C}$ & $\mathbf{C C}$ & H \\
\hline $\mathrm{Cu}$ & $0.017 \pm 0.002 \mathrm{a}$ & $0.016 \pm 0.001 \mathrm{ab}$ & $0.017 \pm 0.001 \mathrm{~b}$ \\
\hline $\mathrm{Fe}$ & $0.4 \pm 0.3 \mathrm{a}$ & $0.3 \pm 0.3 \mathrm{a}$ & $0.2 \pm 0.3 \mathrm{a}$ \\
\hline $\mathrm{Ca}^{2+}$ & $23.9 \pm 3.3 \mathrm{ab}$ & $26.7 \pm 1.8 \mathrm{a}$ & $28.6 \pm 2.1 \mathrm{~b}$ \\
\hline $\mathrm{K}^{+}$ & $8.4 \pm 0.5 \mathrm{ab}$ & $10.1 \pm 1.9 \mathrm{a}$ & $13.6 \pm 3.5 \mathrm{a}$ \\
\hline $\mathrm{Mg}^{2+}$ & $5.8 \pm 0.7 \mathrm{a}$ & $4.8 \pm 0.3 \mathrm{~b}$ & $6.6 \pm 0.7 \mathrm{~b}$ \\
\hline $\mathrm{Na}^{+}$ & $1.6 \pm 0.2 \mathrm{ab}$ & $0.2 \pm 0.3 \mathrm{a}$ & $2.5 \pm 0.7 \mathrm{~b}$ \\
\hline $\mathrm{P}$ & $0.9 \pm 0.1 \mathrm{ab}$ & $0.9 \pm 0.3 \mathrm{a}$ & $1.4 \pm 0.2 \mathrm{~b}$ \\
\hline $\mathrm{N}$ & $19.6 \pm 0.3 \mathrm{a}$ & $19.2 \pm 3.7 \mathrm{a}$ & $15.1 \pm 2 \mathrm{a}$ \\
\hline
\end{tabular}

\begin{tabular}{|l|c|c|c|}
\hline \multicolumn{4}{|c|}{ Festuca nigrescens } \\
\hline Element $\left(\mathbf{m g ~ g}^{-1}\right)$ & $\mathbf{C}$ & $\mathbf{C C}$ & $\mathbf{H}$ \\
\hline $\mathrm{Cu}$ & $0.008 \pm 0.0002 \mathrm{a}$ & $0.007 \pm 0.0 \mathrm{a}$ & $0.008 \pm 0.002 \mathrm{a}$ \\
\hline $\mathrm{Fe}$ & $0.5 \pm 0.6 \mathrm{a}$ & $0.2 \pm 0.0 \mathrm{a}$ & $0.2 \pm 0.1 \mathrm{a}$ \\
\hline $\mathrm{Ca}^{2+}$ & $12.8 \pm 0.3 \mathrm{a}$ & $13.2 \pm 0.1 \mathrm{a}$ & $15.2 \pm 0.1 \mathrm{a}$ \\
\hline $\mathrm{K}^{+}$ & $7.6 \pm 2.5 \mathrm{a}$ & $10.6 \pm 1.6 \mathrm{a}$ & $10.1 \pm 2.5 \mathrm{a}$ \\
\hline $\mathrm{Mg}^{2+}$ & $2.6 \pm 0.2 \mathrm{a}$ & $2.7 \pm 0.2 \mathrm{a}$ & $2.9 \pm 0.4 \mathrm{a}$ \\
\hline $\mathrm{Na}^{+}$ & $1.2 \pm 0.2 \mathrm{a}$ & $1.2 \pm 0.05 \mathrm{a}$ & $1.3 \pm 0.2 \mathrm{a}$ \\
\hline $\mathrm{P}$ & $1.1 \pm 0.3 \mathrm{a}$ & $0.8 \pm 0.2 \mathrm{a}$ & $1.5 \pm 0.5 \mathrm{a}$ \\
\hline $\mathrm{N}$ & $18.5 \pm 0.9 \mathrm{a}$ & $14.2 \pm 2.5 \mathrm{~b}$ & $14.1 \pm 2.1 \mathrm{~b}$ \\
\hline
\end{tabular}

Tab. 3 Nutrient content ( $\mathrm{mg} \mathrm{g}^{-1}$ ) in T. pratense (top) and F. nigrescens plants (bottom) at the end of the second growth cycle in control $(\mathrm{C})$, control + fresh charcoal $(\mathrm{CC})$ and charcoal hearth $(\mathrm{H})$ soils. Different letters indicate significant differences among soil treatments at $\mathrm{p} \leq 0.10$. 


\section{FIGURES}

Fig. 1 Aboveground biomass $\left(\mathrm{g} \mathrm{pot}^{-1}\right)$ at the end of the three growth cycles for $T$. pratense (plot a) and F. nigrescens (plot b) in control (C; light grey), control + fresh charcoal (CC; grey), and charcoal hearths (H; black) soils. Different letters indicate significant differences among soil treatments within each plant species.

Fig. 2 Total belowground (black) and aboveground biomass (grey) per pot accumulated over the three growth cycles for $T$. pratense and $F$. nigrescens plants grown on control (C), control + fresh charcoal (CC) and charcoal hearth (H) soils. Different letters indicate significant differences among soil treatments within each plant species.

Fig. 3 Root:shoot ratio of total biomass accumulated over the three growth cycles for T. pratense and $F$. nigrescens grown on C (light grey), CC (grey) and H (black) soils. Different letters indicate significant differences among soil treatments within each plant species.

Fig. $4 \mathrm{~N}$ :P ratio of soils (plot a) and of T. pratense and F. nigrescens (plot b) grown in C (light grey), CC (grey) and H (black) soils. The two lines correspond to N:P ratios of 14 (dashed) and 16 (continuous). Different letters indicate significant differences among soil treatments.

Fig. 5 Relationship between plant and soil $\mathrm{P}, \mathrm{K}^{+}, \mathrm{Ca}^{2+}, \mathrm{Na}^{+}, \mathrm{Mg}^{2+}$ content ( $\mathrm{mg} \mathrm{g}^{-1}$ ) (plot a, b, c, d and e, respectively) in T. pratense (circles) and F. nigrescens (triangles) grown in $\mathrm{C}$ (white), CC (grey) and $\mathrm{H}$ (black) soils.

Fig. $6{ }^{13} \mathrm{C}$ discrimination ( $\Delta$ ) of $T$. pratense and F. nigrescens plants after the first (a), second (b) and third growth cycle treatments within each plant species.

Fig. 7 Isotopic signature $\left(\delta^{15} \mathrm{~N}\right)$ of $F$. nigrescens and T. pratense plants after the first (a), second (b) and third growth cycle (c) in C (light grey), CC (grey) and H (black) soils. P-values of the individual comparisons are reported in the two tables. Different letters indicate significant differences among soil treatments within each plant species. 


\section{Online Resource}

506

507 Tab. 1 Recommended nutrients supply of a dairy cow with a mean performance of $30 \mathrm{~kg}$ milk day ${ }^{-1}$ and a daily intake 508 of $20 \mathrm{~kg}$ biomass dry matter (Flachowsky et al. 2001). 
509 Funding: This study was financed by: EuroChar project (FP7-ENV-478 2010ID-265179) funded by the European 510 Commission and AgroPyroGas funded by Regione Toscana, Italy. G.A. was partially supported by a German Academic 511 Exchange Service (DAAD, Germany) scholarship for a three-month research period at University of Freiburg,

512 Germany. I.C. was supported by a Ph.D. grant from Fondazione Edmund Mach, Trento. The funders had no role in 513 study design, data collection and analysis, decision to publish, or preparation of the manuscript.

515 Conflict of Interest: The authors declare that they have no conflict of interest. 
Agren GI, Franklin O (2003) Root: Shoot Ratios, Optimization and Nitrogen Productivity. Ann Bot 92:795-800. doi: $10.1093 / \mathrm{aob} / \mathrm{mcg} 203$

Aronson J, Floret C, LeFloc'h E, et al. (1993) Restoration and Rehabilitation of Degraded Ecosystems in Arid and Semi-Arid Lands . I . A View from the South. Restor Ecol 8-17.

Backmeroff C (2013) Precisely dating iron-ore mining and its effects on an alpine valley: Summary of a dendrochronological investigation of charcoal hearths and relict woodland stands. In: Silvertant J ed. (ed) Min. Cult. Landsc. - 8th Int. Symp. Archaeol. Min. Hist. pp 218-251

Bargmann I, Rillig MC, Buss W, et al. (2013) Hydrochar and Biochar Effects on Germination of Spring Barley. J Agron Crop Sci 199:360-373. doi: 10.1111/jac.12024

Belleri C (2014) L'Oasi di Protezione faunistica del Baremone: analisi e sviluppi.

Bergametti G, Remoudaki E, Losno R, et al. (1992) Source, transport and deposition of atmospheric phosphorus over the northwestern Mediterranean. J Atmos Chem 14:501-513.

Biederman L a., Harpole WS (2013) Biochar and its effects on plant productivity and nutrient cycling: a meta-analysis. GCB Bioenergy 5:202-214. doi: 10.1111/gcbb.12037

Bovolenta S, Dovier S, Parente G (2011) Dairy production systems in the Italian alpine area. Proceeding 16 th Meet. FAO CIHEAM Mt. Pastures Netw. Kraków, POLAND, pp 137-140

Brugnoli E, Hubick KT, von Caemmerer S, et al. (1989) Correlation between the Carbon Isotope Discrimination in Leaf Starch and Sugars of C3 Plants and the Ratio of Intercellular and Atmospheric Partial Pressures of Carbon Dioxide. Plant Physiol 88:1418-1424. doi: 10.1104/pp.88.4.1418

Case SDC, McNamara NP, Reay DS, Whitaker J (2012) The effect of biochar addition on N2O and CO2 emissions from a sandy loam soil - The role of soil aeration. Soil Biol Biochem 51:125-134. doi: 10.1016/j.soilbio.2012.03.017

Chen W, Cui P, Sun H, et al. (2009) Comparative effects of salt and alkali stresses on organic acid accumulation and ionic balance of seabuckthorn ( Hippophae rhamnoides L .). Ind Crops Prod 30:351-358. doi: 10.1016/j.indcrop.2009.06.007

Ciais P, Soussana JF, Vuichard N, et al. (2010) The greenhouse gas balance of European grasslands. Biogeosciences Discuss 7:5997-6050. doi: 10.5194/bgd-7-5997-2010

Criscuoli I, Alberti G, Baronti S, et al. (2014) Carbon sequestration and fertility after centennial time scale incorporation of charcoal into soil. PLoS One 9:e91114. doi: 10.1371/journal.pone.0091114

Dullinger S, Dirnbock T, Greimler J, Grabherr G (2003) A resampling approach for evaluating effects of pasture abandonment on subalpine plant species diversity. J Veg Sci 14:243-252.

Fang Y, Singh B, Singh BP (2015) Effect of temperature on biochar priming effects and its stability in soils. Soil Biol Biochem 80:136-145. doi: 10.1016/j.soilbio.2014.10.006

FAO (1985) Simple technologies for charcoal making. Mechanical Wood Products Branch Forest Industries Division FAO Forestry Department, Rome

FAO (2002) FAO IRRIGATION AND DRAINAGE PAPER 61 Agricultural drainage water management in arid and semi-arid areas. Rome, Italy

Farquhar G, Richards R (1984) Isotopic Composition of Plant Carbon Correlates With Water-Use Efficiency of Wheat Genotypes. Aust J Plant Physiol 11:539. doi: 10.1071/PP9840539

Flachowsky G, Jeroch H, Kirchgessner M, et al. (2001) Empfehlungen zur Energie- und Nahrstoffversorgung der Milchkuhe und Aufzuchtrinder. (Recommendations for the energy- and nutrient supply of dairy cows and breeding cattle). DLG-Verlag GmbH, Frankfurt am Main, Germany

Flematti GR, Ghisalberti EL, Dixon KW, Trengove RD (2008) Germination stimulant in smoke: isolation and identification. Bioact. Nat. Prod. Detect. Isol. Struct. Elucidation

Flematti GR, Ghisalberti EL, Dixon KW, Trengove RD (2004) A compound from smoke that promotes seed germination. Science 305:977. doi: 10.1126/science.1099944

Flematti GR, Scaffidi A, Dixon KW, et al. (2011) Production of the seed germination stimulant karrikinolide from 
combustion of simple carbohydrates. J Agric Food Chem 59:1195-8. doi: 10.1021/jf1041728

Fontana V, Radtke A, Bossi Fedrigotti V, et al. (2013) Comparing land-use alternatives: Using the ecosystem services concept to define a multi-criteria decision analysis. Ecol Econ 93:128-136. doi: 10.1016/j.ecolecon.2013.05.007

Gamper SM, Tasser E, Tappeiner U (2007) Short-time effects of land-use changes on O-horizon in subalpine grasslands. Plant Soil 299:101-115. doi: 10.1007/s11104-007-9366-6

Garnett E, Jonsson LM, Dighton J, Murner K (2004) Control of pitch pine seed germination and initial growth exerted by leaf litters and polyphenolic compounds. Biol Fertil Soils 40:421-426. doi: 10.1007/s00374-004-0801-z

Gell K, van Groenigen J, Cayuela ML (2011) Residues of bioenergy production chains as soil amendments: immediate and temporal phytotoxicity. J Hazard Mater 186:2017-2025. doi: 10.1016/j.jhazmat.2010.12.105

Genesio L, Miglietta F, Lugato E, et al. (2012) Surface albedo following biochar application in durum wheat. Environ Res Lett 7:014025. doi: 10.1088/1748-9326/7/1/014025

Genesio L, Vaccari FP, Miglietta F (2016) Black Carbon aerosol from biochar threats its negative emission potential. Glob Chang Biol. doi: 10.1111/gcb.13254

Glaser B, Haumaier L, Guggenberger G, Zech W (2001) The "Terra Preta” phenomenon: a model for sustainable agriculture in the humid tropics. Naturwissenschaften 88:37-41. doi: 10.1007/s001140000193

Graber ER, Tsechansky L, Mayzlish-Gati E, et al. (2015) A humic substances product extracted from biochar reduces Arabidopsis root hair density and length under P-sufficient and P-starvation conditions. Plant Soil 395:21-30. doi: $10.1007 / \mathrm{s} 11104-015-2524-3$

Greenway H, Munns R (1980) MECHANISMS OF SALT TOLERANCE IN NONHALOPHYTES. Annu Rev Plant Physiol 31:149-190.

Grigulis K, Lavorel S, Krainer U, et al. (2013) Relative contributions of plant traits and soil microbial properties to mountain grassland ecosystem services. 47-57. doi: 10.1111/1365-2745.12014

Güereña DT, Lehmann J, Thies JE, et al. (2015) Partitioning the contributions of biochar properties to enhanced biological nitrogen fixation in common bean (Phaseolus vulgaris). Biol Fertil Soils 51:479-491. doi: 10.1007/s00374-014-0990-z

Hernandez-Soriano MC, Kerré B, Goos P, et al. (2015) Long-term effect of biochar on the stabilization of recent carbon : soils with historical inputs of charcoal. Glob Chang Biol Bioenergy 1-11. doi: 10.1111/gcbb.12250

Hille B (1992) Ionic Channels of Excitable Membranes, 2nd editio. Sinauer

Hille M, Den Ouden J (2005) Charcoal and activated carbon as adsorbate of phytotoxic compounds a comparative study. OIKOS 108:202-207.

Hunziker M (1995) The spontaneous reafforestation in abandoned agricultural lands : perception and aesthetic assessment by locals and tourists. Landsc Urban Plan 1:399-410.

Jeffery S, Verheijen FG a., van der Velde M, Bastos a. C (2011) A quantitative review of the effects of biochar application to soils on crop productivity using meta-analysis. Agric Ecosyst Environ 144:175-187. doi: 10.1016/j.agee.2011.08.015

Jenkins JR, Viger M, Arnold EC, et al. (2016) Biochar alters the soil microbiome and soil function: results of next generation amplicon sequencing across Europe. GCB Bioenergy. doi: 10.1111/gcbb.12371

Johansson K (2008) Salt to ruminants and horses. Uppsala

Juknevičius S, Sabiené N (2007) The content of mineral elements in some grasses and legumes. EKOLOGIJA 53:4452.

Kessler J (2001) Mineralstoffversorgung der Milchkuh auf einen Blick rap aktuell (Mineral nutrient supply of dairy cows at a glance). Villars-sur-Glane

Kloss S, Zehetner F, Dellantonio A, et al. (2012) Characterization of slow pyrolysis biochars: effects of feedstocks and pyrolysis temperature on biochar properties. J Environ Qual 41:990-1000. doi: 10.2134/jeq2011.0070

Koerner C, Renhardt U (1987) Dry matter partitioning and root length / leaf area ratios in herbaceous perennial plants with diverse altitudinal distribution. Oecologia 74:411-418.

Koerselman W, Meuleman AFM (1996) The vegetation N : P ratio : a new tool to detect the nature of nutrient limitation. J Appl Ecol 33:1441-1450.

Kołtowski M, Oleszczuk P (2015) Toxicity of biochars after polycyclic aromatic hydrocarbons removal by thermal 
Kopittke PM, Menzies NW (2007) A Review of the Use of the Basic Cation Saturation Ratio and the "Ideal" Soil. Soil Sci Soc Am J 71:259-265. doi: 10.2136/sssaj2006.0186

Krahulec F, Skálová H, Herben T, et al. (2001) Vegetation changes following sheep grazing in abandoned mountain meadows. Appl Veg Sci 4:97-102. doi: 10.1111/j.1654-109X.2001.tb00239.x

Kuppusamy S, Thavamani P, Megharaj M, et al. (2016) Agronomic and remedial benefits and risks of applying biochar to soil: Current knowledge and future research directions. Environ Int 87:1-12. doi: 10.1016/j.envint.2015.10.018

de la Rosa JM, Knicker H (2011) Bioavailability of N released from N-rich pyrogenic organic matter: An incubation study. Soil Biol Biochem 43:2368-2373. doi: 10.1016/j.soilbio.2011.08.008

Lehmann J, Gaunt J, Rondon M (2006) Bio-char Sequestration in Terrestrial Ecosystems - A Review. Mitig Adapt Strateg Glob Chang 11:395-419. doi: 10.1007/s11027-005-9006-5

Liang B, Lehmann J, Solomon D, et al. (2006) Black Carbon Increases Cation Exchange Capacity in Soils. Soil Sci Soc Am J 70:1719. doi: 10.2136/sssaj2005.0383

Von Liebig J (1840) Die organische chemie in ihrer answendund auf agrikultur und physiologie. Friedrich Vieweg, Braunschweig

Lim TJ, Spokas KA, Feyereisen G, Novak JM (2016) Predicting the impact of biochar additions on soil hydraulic properties. Chemosphere 142:136-144. doi: 10.1016/j.chemosphere.2015.06.069

Di Lonardo S, Vaccari FP, Baronti S, et al. (2013) Biochar successfully replaces activated charcoal for in vitro culture of two white poplar clones reducing ethylene concentration. Plant Growth Regul 69:43-50. doi: 10.1007/s10725012-9745-8

Makoto K, Choi D, Hashidoko Y, Koike T (2011) The growth of Larix gmelinii seedlings as affected by charcoal produced at two different temperatures. Biol Fertil Soils 47:467-472. doi: 10.1007/s00374-010-0518-0

Mäser P, Gierth M, Schroeder JI (2002) Molecular mechanisms of potassium and sodium uptake in plants. Plant Soil 247:43-54.

Maurer K (2005) Natural and anthropogenic determinants of biodiversity of grasslands in the Swiss Alps. Universität Basel

Muller S, Dutoit T, Alard D, Grévilliot F (1998) Restoration and Rehabilitation of Species-Rich Grassland Ecosystems in France : a Review. Restor Ecol 6:94-101.

Naisse C, Girardin C, Davasse B, et al. (2014) Effect of biochar addition on C mineralisation and soil organic matter priming in two subsoil horizons. J Soils Sediments 15:825-832. doi: 10.1007/s11368-014-1002-5

National Research Council (2001) Nutrient Requirements of Dairy Cattle, 7th revise. National Academy Press, Washington, D.C.

Nelson DC, Flematti GR, Ghisalberti EL, et al. (2012) Regulation of seed germination and seedling growth by chemical signals from burning vegetation. Annu Rev Plant Biol 63:107-30. doi: 10.1146/annurev-arplant-042811-105545

Novak J, Sigua G, Watts D, et al. (2016) Biochars impact on water infiltration and water quality through a compacted subsoil layer. Chemosphere 142:160-167. doi: 10.1016/j.chemosphere.2015.06.038

Ogawa M, Okimori Y (2010) Pioneering works in biochar research , Japan. Aust J Soil Res 48:489-500.

Poeplau C, Don A (2013) Sensitivity of soil organic carbon stocks and fractions to different land-use changes across Europe. Geoderma 192:189-201. doi: 10.1016/j.geoderma.2012.08.003

Poschlod P, Wallisdevries MF (2002) The historical and socioeconomic perspective of calcareous grasslands — lessons from the distant and recent past. Biol Conserv 104:361-376.

Pusceddu E, Criscuoli I, Miglietta F (2013) Morphological investigation and physical characterization of ancient fragments of pyrogenic carbon. J Phys Conf Ser 470:012003. doi: 10.1088/1742-6596/470/1/012003

Reid RL, Horvath DJ (1980) Soil chemistry and mineral problems in farm livestock. A review. Anim. Feed Sci. Technol. 5:

Riedener E, Rusterholz H-P, Baur B (2013) Effects of different irrigation systems on the biodiversity of species-rich hay meadows. Agric Ecosyst Environ 164:62-69. doi: 10.1016/j.agee.2012.09.020

Rombolà AG, Marisi G, Torri C, et al. (2015) Relationships between Chemical Characteristics and Phytotoxicity of Biochar from Poultry Litter Pyrolysis. J Agric Food Chem 63:6660-6667. doi: 10.1021/acs.jafc.5b01540 
Rondon M a., Lehmann J, Ramírez J, Hurtado M (2006) Biological nitrogen fixation by common beans (Phaseolus vulgaris L.) increases with bio-char additions. Biol Fertil Soils 43:699-708. doi: 10.1007/s00374-006-0152-z

Schachtman D, Liu W (1999) Molecular pieces to the puzzle of the interaction between potassium and sodium uptake in plants. Trends Plant Sci 4:281-287.

Schimmelpfennig S, Kammann C, Moser G, et al. (2015) Changes in macro- and micronutrient contents of grasses and forbs following Miscanthus x giganteus feedstock, hydrochar and biochar application to temperate grassland. Grass Forage Sci 70:582-599. doi: 10.1111/gfs.12158

Schimmelpfennig S, Müller C, Grünhage L, et al. (2014) Biochar, hydrochar and uncarbonized feedstock application to permanent grassland-Effects on greenhouse gas emissions and plant growth. Agric Ecosyst Environ 191:39-52. doi: 10.1016/j.agee.2014.03.027

Smith RT, Atkinson K (1975) Techniques in pedology. Paul Elek (Scientific Books) Ltd., London

Sohi S, Lopez-capel E, Krull E, Bol R (2009) Biochar, climate change and soil : A review to guide future research.

Solaiman ZM, Murphy D V., Abbott LK (2011) Biochars influence seed germination and early growth of seedlings. Plant Soil 353:273-287. doi: 10.1007/s11104-011-1031-4

Spokas K a., Baker JM, Reicosky DC (2010) Ethylene: potential key for biochar amendment impacts. Plant Soil 333:443-452. doi: 10.1007/s11104-010-0359-5

Stanchi S, Freppaz M, Zanini E (2012) The influence of Alpine soil properties on shallow movement hazards, investigated through factor analysis. Nat Hazards Earth Syst Sci 12:1845-1854. doi: 10.5194/nhess-12-1845-2012

Tasser E, Mader M, Tappeiner U (2003) Effects of land use in alpine grasslands on the probability of landslides. Basic Appl Ecol 280:271-280.

Tasser E, Tappeiner U (2002) Impact of land use changes on mountain vegetation. Appl Veg Sci 5:173-184.

Tasser E, Walde J, Tappeiner U, et al. (2007) Land-use changes and natural reforestation in the Eastern Central Alps. Agric Ecosyst Environ 118:115-129. doi: 10.1016/j.agee.2006.05.004

Tozer KN, Rennie GM, King WM, et al. (2013) Pasture renewal on Bay of Plenty and Waikato dairy farms : impacts on pasture production and invertebrate populations post-establishment. Proc New Zeal Grassl Assoc 75:227-234.

USEPA (1996) Method 3052, Microwave assisted aced digestion of siliceous and organically based matrices. 1-20.

Vaccari F., Maienza A, Miglietta F, et al. (2015) Biochar stimulates plant growth but not fruit yield of processing tomato in a fertile soil. Agric Ecosyst Environ 207:163-170. doi: 10.1016/j.agee.2015.04.015

Väre H, Lampinen R, Humphries C, Williams P (2003) Taxonomic Diversity of Vascular Plants in the European Alpine Areas. Alp. Biodivers. Eurupe

Ventura M, Alberti G, Viger M, et al. (2015) Biochar stability and priming effect on SOM decomposition in two European short rotation coppices. Glob Chang Biol Bioenergy 7:1150-1160.

van de Voorde TFJ, Bezemer TM, Van Groenigen JW, et al. (2014) Soil biochar amendment in a nature restoration area : effects on plant productivity and community composition. Ecol Appl 24:1167-1177.

Wang J, Xiong Z, Kuzyakov Y (2015) Biochar stability in soil: meta-analysis of decomposition and priming effects. GCB Bioenergy n/a-n/a. doi: 10.1111/gcbb.12266

Van Zwieten L, Rose T, Herridge D, et al. (2015) Enhanced biological N2 fixation and yield of faba bean (Vicia faba L.) in an acid soil following biochar addition: dissection of causal mechanisms. Plant Soil 395:7-20. doi: $10.1007 / \mathrm{s} 11104-015-2427-3$ 